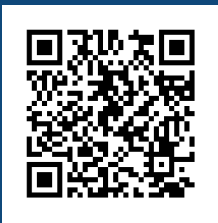

Keywords:

Soil physical properties

OM analys

Production system

Ecological restoration
Correspondence: elainenovak_@hotmail.com
Elaine Novak ${ }^{\mathrm{la}+}$, Laércio Alves de Carvalho ${ }^{\mathrm{b}}$, Etenaldo Felipe Santiago ${ }^{\mathrm{c}}$, Michely Tomazi ${ }^{2 a}$

\section{CHANGES IN THE SOIL STRUCTURE AND ORGANIC MATTER DYNAMICS UNDER DIFFERENT PLANT COVERS}

NOVAK, E.; CARVALHO, L. A.; SANTIAGO, E. F; TOMAZI, M. Changes in the soil structure and organic matter dynamics under different plant covers. CERNE, v. 25, n. 2, p.230-239, 2019.

\section{HIGHLIGHTS}

The cultivation of sugarcane resulted in changes in soil quality.

The restitution of soil integrity parameters in areas that have undergone replanting of vegetation cover by planting native seedlings or suspending management with agricultural activities present their own dynamics, even in areas with relative proximity, type and classification of soil , suggesting interactions associated with biological activity, deposition and behavior of organic matter in soils.

In spite of the increasing demand on the issues about the importance of recovery of forest resources and the need to preserve them, especially those with specific functions and occupying areas of permanent preservation, the studies that guide and evaluate the restoration of these areas are still insufficient due to the complexity of the ecological processes involved.

\section{ABSTRACT}

The soil properties reported in areas with different management provide useful information about the systems' operation, state of conservation and resilience. In this way, this study evaluated physical properties and organic matter dynamics of soil under different plant covers in seven areas consisting of: five areas under ecological restoration (RECI to REC5), an areas with native vegetation (MATA) and a sugarcane crop area (SC), all located in State of Mato Grosso do Sul, a transition area between the Cerrado and Atlantic Forest biomes. Samples were taken at the 0-10 and 10-20 cm layers and were analyzed for soil density (Ds), macroporosity (Ma), microporosity (Mi), total porosity (PT), weighted mean diameter (DMP), aggregate stability index (IEA), and the particle sizes of organic matter. There were no differences in DMP between the areas, however, sugarcane crop area and areas under ecological restoration (REC I, 3 and 4) had high values of density and microporosity and low contents of the fractions of organic matter, which can promote a greater restriction to the root development of plants. Among the areas under restoration, $\mathrm{RECl}$ and REC5 presented physical conditions with higher similarity to the native vegetation area. Changes in the physical soil properties and parameters such as Total organic carbon (COT), confirmed that the restoration practices applied improved the soil quality.
' Federal Institute of Paraná, CIDADE, Paraná, Brazil - ORCID: 0000-0002-1027-3534ª, 0000-0003-0034-8237', 0000-000 I-6838-1098c,

2EMBRAPA Agropecuária Oeste, Dourados, Mato Grosso do Sul, Brazil - ORCID: 0000-0002-36 18-2403a 


\section{INTRODUCTION}

Soil quality can be defined as the ability of a soil to function within the limits of ecosystems (natural or cultivated) to perform one or more functions related to plant sustainability and productivity, maintain or improve environmental quality and health promotion of animals and man (Karlen et al., 1997). The sustainability of an environment can be estimated by the evaluation and monitoring of soil properties that are sensitive to changes through use and management over time, from which the evolution of soil quality is evaluated (Nascimento et al., 20I4). Understanding the interactions between plant biodiversity, soil properties and their impact changes can be useful in restoration actions in degraded areas (Mueller et al., 20I4) in the long term, and serves as an important tool to monitor the state of conservation of natural ecosystems, because they allow to characterize the current situation, to alert to situations of risk and, sometimes, to predict future situations, especially when adopting native vegetation as reference (Cardoso et al., 20 I I).

Studies have demonstrated the importance of indicators as a mechanism for understanding the quality or state of conservation of several systems (Aragão et al., 2012; Moline and Coutinho, 2015; Cherubin et al., 2016). Among the physical properties, aggregate stability has been used worldwide as an indicator of soil quality (Duchicela et al., 2013; Spaccini and Piccolo, 2013; Stott et al., 20I3; Karlen, 20I4; Zornoza et al., 20I5) due to its crucial role in stabilizing and protecting carbon in physical processes related to water and air dynamics, and providing resistance against soil erosion (Cherubin et al., 2016), as well as being an essential property to plant development, because it describes the desirable physical conditions in which the soil is friable and contains a set of pores that allows the movement of water and air that contributes to the germination and emergence process of seedlings (Niewczas and Witkowska-Walczak, 2005).

The content and dynamics of soil organic matter (MOS) are also properties representing soil quality and that can be altered with soil use and management (Guimarães et al., 20I3). A soil with good quality should not only present high levels of MOS, it also needs a balance between the stages of organic matter decomposition (Caetano et al., 20l3). The components that can be considered as good indicators of soil quality include the labile (with lower degree of decomposition) (Loss et al., 2009) and stable (high degree of decomposition) fractions. By means of the particle size fractionation of MOS it is possible to quantify the COp and the organic carbon associated with mineral (COam) (Cambardella and Elliott, 1992), which are efficient fractions to identify changes resulting from soil management practices or the replacement of natural areas by agricultural crops (Torres et al., 20I4) over the years.

From the practical point of view and considering the environmental interest, studies on changes in soil structure (Portugal et al., 20l0) and soil organic matter dynamics induced by the soil management is of major importance to understand the effects of use and land occupation, adoption of support restorative practices and help in understanding ecological processes advocated by the ecology of restoration.

\section{MATERIAL AND METHODS}

\section{Study area characterization}

The study was carried out in the municipality of Rio Brilhante, State of Mato Grosso do Sul (21 ${ }^{\circ} 48^{\prime} \mathrm{S} /$ $44^{\circ} 32^{\prime}$ ' W). The soil is classified as Hapludox Eutrophic, and is of clayey texture (Embrapa et al., 20I3). According to the Köppen classification system (Cwa), the climate is characterized as humid mesothermal, hot summers and dry winters. The study areas consisted of a remnant of native vegetation, with floristic physiognomy of a transition area between Cerrado and Atlantic Forest, which was adopted as a reference area and identified as MATA, and five areas under ecological restoration (identified as RECI to REC5) and an area of sugarcane crop (SC).

The sugarcane (RB86 - 7515) planting was performed with conventional tillage using harrow plow, one sub soiling to a $0,45 \mathrm{~m}$ of depth and a leveling harrowing. During the planting crop was used NPK fertilizer (05-15-10), and to the annual cuts the replacement was done using NPK fertilizer (30-05-25) in the rows of the crop. To the cultivation of sugarcane ratoon crop operations was carried out between the rows, to minimize the effects of soil compaction caused by intensive traffic of machines in the harvest. At sampling (rainy season 2014), the sugarcane crop was at the fourth mechanized harvest.

The areas under restoration were originally established in a seasonal semi-deciduous forest and replaced by pasture (Brachiaria brizantha), managed in a ten year-period, and later by the sugarcane crop for two years. After this period, areas were allowed for environmental recovery. Due to the location, fragments destined for recovery were identified as RECI to REC5, with the adoption of natural recovery and planting of native forest species, such as Myracrodruon urundeuva, Schinus 
terebinthifolia, Handroanthus avellanedae, Machaerium stipitatum and Dabergia miscolobium, among others, in the area identified as REC2 and natural recovery in other areas. In all areas there was no mechanical intervention and fertilizer application.

\section{Experimental design}

Soil density (Ds), total porosity (PT), macroporosity $(\mathrm{Ma})$ and microporosity $(\mathrm{Mi})$ were calculated using undisturbed samples collected with Uhland sampler in steel cylinders (Kopecky) with sharp edges and internal volume of $100 \mathrm{~cm}^{3}$ at the layers $0-10$ and $10-20 \mathrm{~cm}$, with four random replicates in each layer in the evaluated areas.

To evaluate the aggregation and stability of aggregates and carbon fractions, four small trenches were dug with the aid of a straight blade to allow the removal of soil monoliths in the $0-10$ and $10-20 \mathrm{~cm}$ layers in each area studied. Samples were stored in plastic bags of $10 \times 10 \times 10 \mathrm{~cm}$ that allowed the storage and transportation without major damage to the samples.

\section{Laboratory procedures}

For the determination of soil density and total porosity (macroporosity and microposity) according to the methodology described by Embrapa (1997). For evaluation of aggregates and determination of their stability, we adopted the procedure of Kemper and Rosenau (1986), modified by Salton et al. (20I2).

For the determination of total carbon content, an aliquot of each class of soil aggregates obtained was completely ground and sieved through $0.150 \mathrm{~mm}$ mesh sieves, with a subsequent weighing of $0.150 \mathrm{~g}$ of this aliquot for dry combustion analysis (TOC- L, Shimadzu ${ }^{\circledR}$ ).

The evaluation of the MOS fractions (COp and COam) was performed using the particle size fractionation method described by Cambardella and Elliot (1992). The carbon stock in organic matter associated with mineral (COam) was calculated by the difference between the COT and COp (>0.053 mm) (Torres et al., 20l4).

\section{Statistical analysis}

The obtained data were subjected to the ShapiroWilk test to check normality and the Levene's test to check homoscedasticity. Data that presented normality and homoscedasticity were tested by analysis of variance (ANOVA), and the means were compared by the Tukey's test, at $5 \%$ significance.

Data of the analyzed variables were also subjected to Pearson correlation and multivariate analysis, among which, principal component analysis (PCA), using the Vegan package in the software platform $R(R$ Development Core Team, 2015) and cluster analysis, using the furthest neighbor method (complete linkage) and Euclidean distance to describe the similarity between evaluated areas.

\section{RESULTS AND DISCUSSION}

Changes in soil physical properties and Distribution of soil aggregate classes

At the $0-10 \mathrm{~cm}$ layer, the lowest values of soil density (Ds) were observed in the area with native vegetation and the largest values, in the sugarcane crop area. The areas under ecological restoration presented intermediate values, however, it is noticed that RECI and REC5 presented values closer to the area MATA (Table I). Our findings corroborate Silva et al. (2013), who found lower values of Ds in native vegetation area. According to the authors, this fact may be related to higher carbon contents, as observed in herein (Figure IA), and by Blum et al. (2014) evaluating the physical properties of a Typic Hapludox subjected to a no-till system. It may be also related to the great biological diversity (Gama-Rodrigues et al., 2008), favored by the deposition of diversified plant residues.

Nevertheless, based on the critical values of Tormena et al. (2008), who consider critical values of Ds above $1.16 \mathrm{~g} \cdot \mathrm{cm}^{-3}$ for clayey soils, and Reichert et al. (2009), values above $1.35 \mathrm{~g} \cdot \mathrm{cm}^{-3}$ as critical for the establishment of the root system of plants in very clayey soils (62\% clay), only the area under native forest did not present values of Ds potentially restrictive to development of plants in the surface layer.

In turn, at the 10-20 cm layer, the results indicated that the restoration areas REC2 and REC3 presented high values of Ds, not statistically differing from SC. The other areas under restoration (RECI, REC4 and REC5) presented intermediate Ds values, not differing from the native vegetation and sugarcane crop areas, which presented statistically lower values. Adopting the criterion established by Reichert et al. (2009), RECI, REC5 and MATA did not present Ds values that could impair the root growth of plants, since they are associated with soil clay content. On the other hand, the substitution of native vegetation for production systems probably induced soil compaction due to the increase in Ds values and Ma decrease, as pointed out by Cherubin et al. (2016). 
TABLE I Mean values of soil Density (Ds), Macroporosity (Ma), Microporosity (Mi), Total Porosity (PT) and particle size analysis in the $0-10 \mathrm{~cm}$ and $10-20 \mathrm{~cm}$ layers in areas under ecological restoration, native vegetation and cultivation of sugarcane.

\begin{tabular}{|c|c|c|c|c|c|c|c|c|c|c|c|}
\hline \multirow[b]{2}{*}{ Areas } & \multirow{2}{*}{\multicolumn{2}{|c|}{$\frac{\mathrm{Ds}}{\mathrm{g} \cdot \mathrm{cm}^{-}}$}} & \multicolumn{2}{|c|}{$\mathrm{Ma}$} & \multicolumn{2}{|c|}{$\mathrm{Mi}$} & \multirow{2}{*}{\multicolumn{2}{|c|}{ PT }} & \multicolumn{3}{|c|}{ Particle size (\%) } \\
\hline & & & \multicolumn{4}{|c|}{$\mathrm{cm}^{3} \cdot \mathrm{cm}^{-3}$} & & & Sand & Silt & Clay \\
\hline \multicolumn{12}{|c|}{ Layer $0-10 \mathrm{~cm}$} \\
\hline RECI & $\mathrm{I} .22 \mathrm{bc}$ & \pm 0.08 & $0.16 \mathrm{a}$ & \pm 0.029 & $0.29 \mathrm{~b}$ & \pm 0.083 & $0.45 \mathrm{a}$ & \pm 0.079 & 25.0 & 15.0 & 60.0 \\
\hline REC2 & I.34 abc & \pm 0.03 & $0.06 \mathrm{bc}$ & \pm 0.004 & $0.44 \mathrm{a}$ & \pm 0.015 & $0.5 \mathrm{I} \mathrm{a}$ & \pm 0.018 & 28.7 & 15.0 & 56.2 \\
\hline REC3 & $1.4 \mid \mathrm{ab}$ & \pm 0.03 & $0.05 \mathrm{c}$ & \pm 0.005 & $0.43 \mathrm{ab}$ & \pm 0.007 & $0.48 \mathrm{a}$ & \pm 0.005 & 27.5 & 17.5 & 55.0 \\
\hline REC4 & $1.39 \mathrm{ab}$ & \pm 0.04 & $0.06 \mathrm{bc}$ & \pm 0.006 & $0.43 \mathrm{a}$ & \pm 0.010 & $0.50 \mathrm{a}$ & \pm 0.013 & 25.0 & 12.5 & 62.5 \\
\hline REC5 & $1.21 \mathrm{bc}$ & \pm 0.02 & $0.14 \mathrm{a}$ & \pm 0.004 & $0.38 \mathrm{ab}$ & \pm 0.008 & $0.52 \mathrm{a}$ & \pm 0.004 & 25.0 & 15.0 & 60.0 \\
\hline SC & $1.47 \mathrm{a}$ & \pm 0.01 & $0.07 b c$ & \pm 0.007 & $0.37 \mathrm{ab}$ & \pm 0.003 & $0.44 \mathrm{a}$ & \pm 0.007 & 23.7 & 13.7 & 62.5 \\
\hline MATA & $1.15 c$ & \pm 0.05 & $0.12 \mathrm{ab}$ & \pm 0.003 & $0.38 \mathrm{ab}$ & \pm 0.013 & $0.5 \mathrm{I} \mathrm{a}$ & \pm 0.020 & 22.5 & 17.5 & 60.0 \\
\hline \multicolumn{12}{|c|}{ Layer $10-20 \mathrm{~cm}$} \\
\hline RECI & $1.34 \mathrm{ab}$ & \pm 0.07 & $0.11 \mathrm{a}$ & \pm 0.023 & $0.39 \mathrm{bc}$ & \pm 0.014 & $0.5 \mathrm{Iab}$ & \pm 0.012 & 21.2 & 15.0 & 63.7 \\
\hline REC2 & $1.43 \mathrm{a}$ & \pm 0.02 & $0.04 \mathrm{~b}$ & \pm 0.003 & $0.43 a b$ & \pm 0.006 & $0.47 c d$ & \pm 0.005 & 28.7 & 15.0 & 56.2 \\
\hline REC3 & $1.45 \mathrm{a}$ & \pm 0.04 & $0.05 \mathrm{~b}$ & \pm 0.006 & $0.44 \mathrm{a}$ & \pm 0.009 & $0.49 a b c$ & \pm 0.005 & 27.5 & 16.2 & 56.2 \\
\hline REC4 & I.40 ab & \pm 0.06 & $0.04 \mathrm{~b}$ & \pm 0.010 & $0.42 a b$ & \pm 0.002 & $0.47 \mathrm{bcc}$ & \pm 0.008 & 25.0 & 10.0 & 65.0 \\
\hline REC5 & $1.28 \mathrm{ab}$ & \pm 0.02 & $0.12 \mathrm{a}$ & \pm 0.015 & $0.40 \mathrm{abc}$ & \pm 0.010 & $0.52 \mathrm{a}$ & \pm 0.008 & 23.7 & 13.7 & 62.5 \\
\hline SC & $1.46 \mathrm{a}$ & \pm 0.02 & $0.06 \mathrm{~b}$ & \pm 0.009 & $0.38 \mathrm{~cd}$ & \pm 0.004 & $0.44 \mathrm{~d}$ & \pm 0.005 & 22.5 & 10.0 & 67.5 \\
\hline MATA & $1.21 \mathrm{~b}$ & \pm 0.03 & $0.14 \mathrm{a}$ & \pm 0.009 & $0.34 \mathrm{~d}$ & \pm 0.011 & $0.49 a b c$ & \pm 0.010 & 22.5 & 12.5 & 65.0 \\
\hline
\end{tabular}

Means followed by different letters in the same column are significantly different by Tukey's test at $5 \%$ probability. RECI (area under ecological restoration I), REC2 (area under ecological restoration 2), REC3 (area under ecological restoration 3), REC4 (area under ecological restoration 4), REC5 (area under ecological restoration 5), SC (Sugarcane), MATA (fragment of native Seasonal Semi-deciduous Forest). \pm Standard error

Based on the results of macroporosity of both layers, it can be observed that RECI and REC5 were not significantly different from MATA, reflecting in a better state of physical recovery of the soil. The other areas under restoration (REC2, REC3 and REC4) showed similar values to the sugarcane crop area (SC), indicating unfavorable structural conditions to the full development of plants, when adopting as critical the values below 0.10 $\mathrm{m}^{3} \cdot \mathrm{m}^{-3}$ (Taylor and Ashcroft, 1972).

The volume of micropores in the superficial layer was high in all evaluated areas, except for RECI, which presented statistically lower values. In the subsurface layer, the lowest volume was observed in MATA, followed by SC. However, greater microporosity does not necessarily imply restrictions on plant development, since the soil conservation status should also take into account the values of macroporosity, soil density, penetration resistance, among others. Thus, analyzing the set of physical variables measured in this work, the areas MATA, RECI, REC5 presented a better state of physical conservation of the soil.

Values of total porosity ranged from 0.44 to 0.52 $\mathrm{m}^{3} \cdot \mathrm{m}^{-3}$, reflecting good physical soil quality in the surface layer, according to Kiehl (1979), who considers that the ideal distribution of total porosity is close to $0.50 \mathrm{~m}^{3} \cdot \mathrm{m}^{-3}$. At the 10-20 cm layer, REC2, REC4 and SC presented statistically lower values in comparison to the other areas evaluated. In these areas, in both layers, it can be inferred a greater restriction to the root development of plants, since the values of total porosity in these areas are result of the low macroporosity and high volume of micropores and density value that imply a greater degree of soil compaction. In MATA, the good distribution of total pores may be associated with root system diversity
(Calgaro et al., 2015) and the edaphic community, input of organic matter of varied composition and absence of machinery traffic (Mazurana et al., 2017;), which has significative effect on soil compaction (Feng et al., 2019) in agricultural systems.

In the areas under ecological restoration, besides the forest species, grasses are important in the addition of organic material and soil restructuring (Assad, 1997; Talema et al., 2019), since they have a root system capable of forming continuous channels of pores, water storage in the soil and soil decompaction (Marchini et al., 20I5), a fact that may have contributed to the process of restoration of soil physical properties in some restoration areas.

When analyzing soil aggregation in different areas, the results indicated no significant difference in the values of DMPs and DMPu in both studied layers end little variation in the sites (data not show). Clayey soils with predominance of grasses, without turning over and with constant input of carbon, in general, present good aggregation. This can be related to the root system of plants and to the degree of soil consolidation due to its lower mobilization (Veiga et al., 20l4). Moreover, researchers have reported that high carbon contents (Loss et al., 2014), clay and root production result in higher DMP values (Vezzani and Mielniczuk, 20I I).

Salton et al. (2014) stressed that larger and more stable aggregates are the result of increased biological activity, including the growth of roots and fungal hyphae and the presence of residues of plants, insects and other organisms. Under these conditions, more complex and variable structures are formed, including macroaggregates. In this context, Fattet et al. (20I I) and An et al. (2013) verified the importance of roots in soil 
stability and demonstrated that herbaceous species are very efficient for the stability of soil aggregates.

Changes in soil organic matter fractions under different plant covers

The total organic carbon (COT) presented a different behavior among the plant covers, with values significantly higher in MATA $\left(41.49 \mathrm{~g} \cdot \mathrm{kg}^{-1}\right)$ and REC5 (32.83 $\left.\mathrm{g} \cdot \mathrm{kg}^{-1}\right)$ and lower in SC and other restoration areas which showed no significant differences from each other in the $0-10 \mathrm{~cm}$ layer (Figure I). At the $10-20 \mathrm{~cm}$ layer, there was no difference in COT concentrations between the studied areas.

The highest COT values registered in MATA and REC5 may be related to the greater diversity of plants and density of tree species, which result in greater input of plant residues to the soil (Alcântara Neto et al., 20I I), the texture and temperature, as reported by Cherubin et al. (2016). This demonstrated that the replacement of native vegetation by sugarcane crop resulted in a reduction in the COT content by $41.21 \%$ in the surface layer, however, the conversion of the sugarcane area into areas under ecological restoration promoted increases of

a.

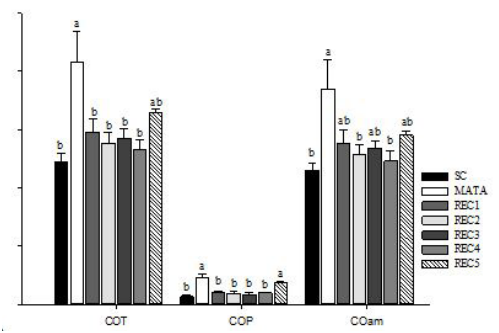

b.

B

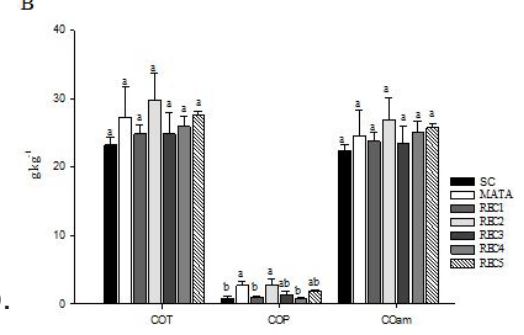

FIGURE I Total organic carbon (COT), particulate organic carbon (COP) and organic carbon associated with mineral (COam) in the $0-10$ (a) and $10-20 \mathrm{~cm}$ (b) layers $(n=4)$ of a Hapludox Eutrophic in Rio Brilhante, State of Mato Grosso do Sul. RECI (area under ecological restoration I), REC2 (area under ecological restoration 2), REC3 (area under ecological restoration 3), REC4 (area under ecological restoration 4), REC5 (area under ecological restoration 5), SC (Sugarcane), MATA (fragment of native Seasonal Semi-deciduous Forest). Different letters for the same fraction of soil organic matter are significantly different by Tukey's test at $5 \%$ probability.
$21.32 \%, 13.53 \%, 17.01 \%, 9.14 \%$ and $34.60 \%$ in $\mathrm{RECI}$, REC2, REC3, REC4 and REC5, respectively, suggesting the existence of a dynamic process of soil improvement.

Reductions in COT levels were reported in the literature as a result of the conversion process and the low carbon input in the system due to the low productivity of dry biomass and inadequate management (Cherubin et al., 2016).

The results obtained in this work corroborate with Batista et al. (2014), which verified that productive systems have lower COT contents when compared to native vegetation (Savana), suggesting incomplete cycles of decomposition and humification of organic matter, thus causing carbon losses during these processes when isolated from sustainable agriculture practices (Naresh et al., 2018).

The concentration of carbon in the particulate organic matter (COp) ranged from $5.38 \%$ to $11.65 \%$ of soil COT in the $0-10 \mathrm{~cm}$ layer, with higher contents in REC5 and MATA (Figure IA). At the $10-20 \mathrm{~cm}$ layer, the COp contents ranged from $3.29 \%$ to $9.59 \%$ of soil COT, with higher values observed in MATA, followed by REC2 and REC5 and the lowest values in $\mathrm{CN}, \mathrm{RECl}$ and REC4 (Figure IB). The negative effect of soil tillage on the particulate fraction of MOS was verified with the reductions of $48.03 \%$ and $38.22 \%$ in SC when compared to MATA in the layers of $0-10$ and $10-20 \mathrm{~cm}$, respectively; thus it represents an efficient and sensitive indicator for detecting changes caused by management. Due to its sensitivity, the particulate fraction can be used as an indicator of soil quality in which changes in soil COT have not yet been of great magnitude (Conceição et al., 2005, Naresh et al., 20l8) and indicate changes in labile carbon resulting from changes in soil use (Loss et al., 20l4).

Regarding the organic carbon associated with minerals (COam), in the superficial layer, the highest content was found in MATA and the lowest, in $\mathrm{CN}$, REC2 and REC4 (Figure IA). At the 10-20 cm layer, it was observed that the use and management of the soil did not affect its proportion (Figure IB). As COam presents a much slower cycling, as for its formation and decomposition, it is necessary a longer period for the alteration of the management systems to have effect on the carbon content of this fraction (Bayer et al., 2004), as verified by Trivedi et al. (20I5), who underpin that the abundance of genes involved in the recalcitrant carbon degradation did not change due to the adopted management practice, indicating that carbon storage in the soil can remain unchanged in the long run. Spaccini 
and Piccolo (20 I 3) highlight that small disturbances on soil from the reduction of tillage methods inhibit the aerobic microbial decomposition of the soil organic matter and, therefore, limit the degradation of soil aggregates and consequently the losses of organic carbon of the system.

Multivariate analysis on physical properties and organic matter fractions of the soil

The explained and cumulative variances of the first two main components extracted in the principal component analysis (PCA), in both layers, accumulated and explained the greater data variability $(77.96 \%$ and $80.83 \%$, respectively). In this way, as the contribution of the other components was minimal, these were not considered in the analysis.

The areas under ecological restoration, sugarcane crop and native vegetation influenced soil physical properties, as indicated by the different groups formed in PCA (Figure 2). The sum of the variability retained in the components explained $77.96 \%$ of the original data variability concerning the effects of the different areas on the physical variables of the soil, in which $\mathrm{PCI}$ and PC2 retained, respectively, $49.98 \%$ and $27.98 \%$ of the information of the surface layer (Figure 2A). At the 10$20 \mathrm{~cm}$ layer, the sum of the variability retained in the components explained $80.83 \%$ of the original variability of the data, in which $\mathrm{PCl}$ and $\mathrm{PC2}$ retained, $47.47 \%$ and $33.36 \%$ of the original information of the data, respectively (Figure $2 \mathrm{~B}$ ).

Analyzing Figure $2 A$ and its respective axes, in the upper left quadrant of the vertical line are the ecological restoration areas, REC2 and REC4, while in the lower left quadrant are REC 3 and SC. The areas REC5 and MATA are in the upper and lower right quadrant, respectively. In Figure 2B, restoration areas REC2 and REC5 are in the upper left quadrant of the vertical line, MATA in the lower left quadrant and REC3, REC4 and SC are in the upper and lower right quadrant, respectively.

At the surface layer, areas under ecological restoration (REC2, REC3 and REC4) were more strongly associated with Ds and $\mathrm{MI}$ contents than with the other physical properties of the soil, and it can be inferred that they are areas that present a greater restriction to the root development of plants due to the possible higher degree of soil compaction. REC5 and MATA presented better physical conditions of the soil in the superficial layer, since they were associated with PT and IEA and the organic matter fractions (COT, COP, COam) and $M A$, respectively, corroborating with Batista et al. (20I4),

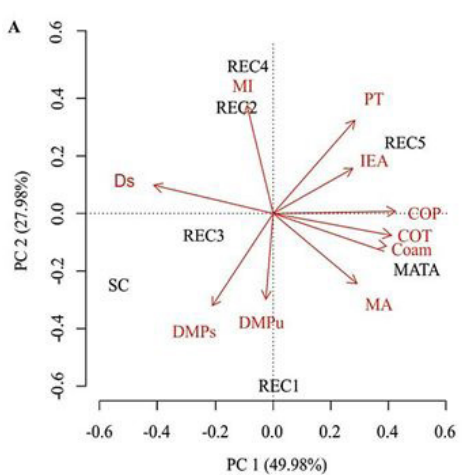

a.

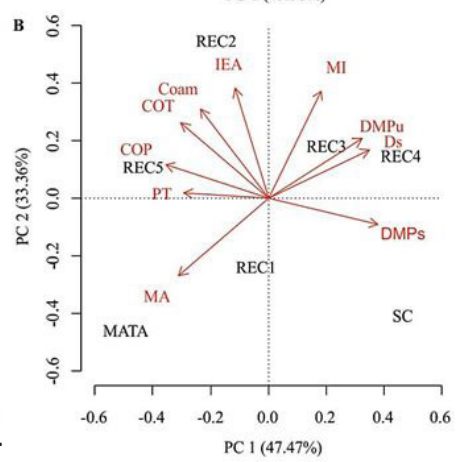

FIGURE 2 Principal Component Analysis (PCA) based on soil physical properties density (Ds), macroporosity (Ma), microporosity (Mi), total porosity (PT), total organic carbon (COT), particulate organic carbon (COP), organic carbon associated with minerals (COam), dry and wet weighted mean diameter (DMPs and DMPu) and aggregate stability index (IEA) in the layers of 0-10 (A) and $10-20 \mathrm{~cm}(B)(n=4)$, of in Rio Hapludox Eutrophic Brilhante, State of Mato Grosso do Sul. $\mathrm{RECl}$ (area under ecological restoration I), REC2 (area under ecological restoration 2), REC3 (area under ecological restoration 3), REC4 (area under ecological restoration 4), REC5 (area under ecological restoration 5), SC (Sugarcane), MATA (fragment of native Seasonal Semi-deciduous Forest).

who observed association of the oxidizable carbon fractions with Savana area.

The best physical conditions of the soil at the $10-20 \mathrm{~cm}$ layer were observed in the group formed by MATA and RECI, and in the group formed by REC2 and REC5 that were associated with high values of MA and IEA, PT, COT, COP and COam, respectively.

With the hierarchical clustering analysis for the set of physical properties studied and the organic matter fractions without distinction of layer, it was possible to divide two interpretive groups (Figure 3). In this analysis, the areas under ecological restoration, sugarcane and native vegetation were grouped according to their degree of similarity, classifying them into homogeneous groups, confirming the distribution of areas in the PCA. 
In the interpretation of the similarity matrix between the areas, a cut was made in the Euclidean distance at seventy eight, allowing a clear division of groups ordered by means of the set of physical properties and the fractions of organic matter, constituting the group $\mathrm{Gl}$, that encompasses the data representing the areas RECI, REC5 and MATA, and the Gll group formed by REC2, REC3, REC4 and SC. Nevertheless, when cutting the Euclidean distance at forty-two, demonstrating the areas with the highest similarity, four groups were formed: I and IV represented by $\mathrm{RECI}$ and $\mathrm{CN}$, respectively, were isolated from the other areas, group II formed by MATA and REC5 and group III represented by REC2, REC3 and REC4. The formation of groups with a greater degree of similarity corroborate the concept that the soil management can influence the behavior of the physical properties of the soil, consequently affecting the system resilience.

The clustering analysis of the areas based on the degree of similarity, without taking into account the soil layers, allowed to infer that the areas under restoration present different dynamics regarding the restitution of integrity parameters, since only two of the five areas under restoration studied showed greater similarity with native vegetation area and the others presented greater physical restraint of the soil and greater similarity with the area of sugarcane crop.

These results allow to infer that the reduction of the cultural management and gradual increase of the plant diversity by restoration practices and successional process are followed by greater deposition of plant residues with varied composition and protection of the organic matter

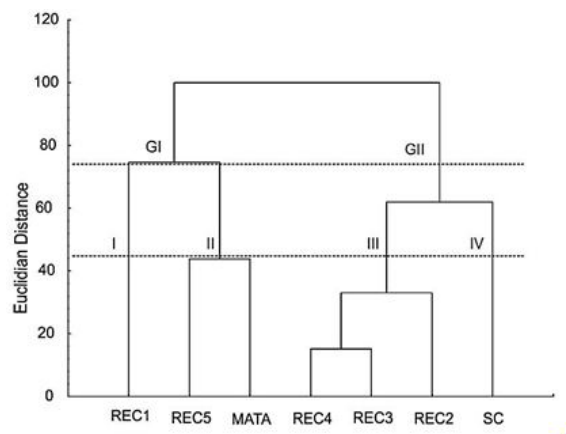

FIGURE 3 Euclidean distance dendrogram based on soil physical properties in areas of ecological restoration, native vegetation, and sugarcane crop. RECI (area under ecological restoration I), REC2 (area under ecological restoration 2), REC3 (area under ecological restoration 3), REC4 (area under ecological restoration 4), REC5 (area under ecological restoration 5), SC (Sugarcane), MATA (fragment of native Seasonal Semi-deciduous Forest). of the soil associated to the improvement of the soil properties and quality. These factors are important and related to the increase of resilience in these places.

The modern production, especially in tropical countries, need to be supported by sustainable practices that are important to the environment preservation and protective to human and soil health. Conservation agriculture practices increase soil quality, providing sustainable food production with minimal impact on the soil and the atmosphere (Naresh et al. 20l8).

The adoption of management strategies in the area of sugarcane crop, such as the maintenance of straw, application of organic residues as complementary fertilization, adoption of minimum tillage and no-till together with the control of the agricultural machinery traffic can collaborate for the soil fertility, soil carbon sequestration and mitigate deleterious impacts on soil physical properties (Cherubin et al., 2016).

\section{CONCLUSION}

The analyses applied to data of physical properties and fractions of soil organic matter indicated that the traditional soil management resulted in changes in the soil quality, leading to increased density and microporosity, which may reflect higher compaction and attenuation of physical protection of organic matter, as well as surface runoff of water, low infiltration rates.

Among the areas under restoration, $\mathrm{RECl}$ and REC5, in general, presented physical properties and organic matter fractions of the soil with greater similarity to the native vegetation area, which indicates that in these areas the intervention was most efficient.

The restitution of soil integrity parameters in areas that underwent replanting of vegetation cover by planting native seedlings or suspending management with agricultural activities has its own dynamics, even in relatively close areas, with similar soil type and classification, suggesting interactions associated with biological activity, deposition and behavior of organic matter in soils.

\section{ACKNOWLEDGMENT}

EMBRAPA Agropecuária Oeste, Fábio Martins Mercante (in memorian), FUNDECT, USINA Louis Dreyfus Group Company.

\section{REFERENCES}

ALCÂNTARA NETO, F.; LEITE, L.F.C.; ARNHOLD, E.; MACIEL, G.A.; CARNEIRO, R.F.V. Comportamento de carbono em latossolo Vermelho sob cultivo de eucalipto e fitofisionomias de Cerrado. Revista Brasileira de Ciência do Solo, v.35, p.849-856, $20 \mathrm{I}$ I. 
AN, S.; DARBOUX, F.; CHENG, M. Revevetation as na eficiente means of increasing soil aggregate stability on the Loess Plateau (China). Geoderma, v.209-2 I0, p. 75-85, 2013.

ARAGÃO, D.V.; CARVALHO, C.J.R.; KATO, O.R.; ARAÚJO, C.M.; SANTOS, M.T.P.; MOURÃO JÚNIOR, M. Avaliação de indicadores de qualidade do solo sob alternativas de recuperação no Nordeste Paraense. Acta Amazônica, v.42, n.I, p. II-I8, 2012.

ASSAD, M. L. L. Fauna do solo. In: VARGAS, M. A. T.; HUNGRIA, M. Biologia dos solos dos Cerrados. Planaltina: EMBRAPA, 1997. 524p.

BATISTA, I.; CORREIA, M.E.F; PEREIRA, M.G.; BIELUCZYK, W.; SCHIAVO, J.A.; ROUWS, J.R.C. Frações oxidáveis do carbono orgânico total e macrofauna edáfica em sistema de integração lavoura-pecuária. Revista Brasileira de Ciência do Solo, v.38, p.797-809, 2014.

BAYER, C.; MARTIN-NETO, L.; MIELNIZUK, J.; PAVINATO, A. Armazenamento de carbono em frações lábeis da matéria orgânica de um Latossolo Vermelho sob plantio direto. Pesquisa Agropecuária Brasileira, v.39, n.7, p.677-683, 2004.

BLUM, J.;GIAROLA, F.B.; SILVA, A.P.; GUEDES FILHO, O.; SILVA, S.G.C.; EBERHARDT, N.; ARAÚJO, S.R.; Assesment of soil physical atributes at sowing row and inter-row under no-till system. Revista Ciência Agronômica, v.45, n.5, p.888-895, 2014

CAETANO, J.O.; BENITES, V.M.; SILVA, G.P.; SILVA, I.R.; ASSIS, R.L.; CARGNELUTTI FILHO, A. Dinâmica da matéria orgânica de um Neossolo Quartzarênico de Cerrado convertido para cultivo em sucessão de soja e milheto. Revista Brasileira de Ciência do Solo, v.37, p.12451255, 2013.

CALGARO, H.F;; BUZETTI, S.; SILVA, L.R.; STEFANINI, L.; MIRANDA, L.P.M.; MORARES, M.A.; MORAES, M.L.T. Distribuição natural de espécies arbóreas em áreas com diferentes níveis de antropização e relação com os atributos químicos do solo. Revista Árvore, v.39, n.2, p. 233-243, 2015

CAMBARDELLA, C. A.; ELLIOTT, E. T. Particulate soil organicmatter changes across a grassland cultivation sequence. Soil Science Society America Journal, v.56, n.2, p.777783, 1992.

CARDOSO, E.L.; SILVA, M.L.N.; CURI, N.; FERREIRA, M.M.; FREITAS, D.A.F. Qualidade química e física do solo sob vegetação arbórea nativa e pastagens no Pantanal SulMato-Grossense. Revista Brasileira de Ciência do Solo, v.35, p.613-622, 201।

CHERUBIN, M.R.; KARLEN, D.; FRANCO, A.L.C.; CERRI, C.E.P. A soil management assessment framework (SMAF) Evoluation of Brazilian sugarcane expansion on Soil Quality. Soil Sciene Society of America Journal, v.25, p.215226, 2016 .
CONCEIÇÃO, P.C.; AMADO, T.J.C.; MIELNICZUK, J.; SPAGNOLLO, E. Qualidade do solo em sistemas de manejo avaliada pela dinâmica da matéria orgânica e atributos relacionados. Revista Brasileira de Ciência do Solo, v.29, p.777-788, 2005.

DUCHICELA, J.; SULLIVAN, T.S.; BONTTI, E.; BEVER, J.D. Soil aggregate stability increase is strongly related to fungal community succession along na abandoned agricultural fied chronosequence in the Bolivian Altiplano. Journal of Applied Ecology, v.50, p. I266-1273, 2013.

EMPRESA BRASILEIRA DE PESQUISA AGROPECUÁRIA EMBRAPA. Manual de Métodos de Análise de Solo. 2.ed. Rio de Janeiro, Ministério da Agricultura e do Abastecimento, 1997, 212 p.

EMPRESA BRASILEIRA DE PESQUISA AGROPECUÁRIA EMBRAPA. Sistema Brasileiro de Classificação de Solos. 3 ed. Brasília, DF, EMBRAPA, 20I3, 342 p.

FATTET, M., FU, Y., GHESTEM, M., MA, W., FOULONNEAU, M., NESPOULOUS, J., LE BISSONNAIS, Y., STOKES, A. Effects of vegetation type on soil resistance to erosion: relationship between aggregate stability and shear strength. Catena, v.87, p. 60-69, 20I I.

FENG, Y.; WANG, J.; LIU, T.; BAI.; READING, L. Using computed tomograghy images to characterize the effects of soil compaction resulting for large machinery on threedimensional pore characteristcs in na opensat coal mine dump. Journal of Soil and Sedments, v.19, p. I467I478, 2019.

GAMA-RODRIGUES, E.F; GAMA-RODRIGUES, A.C.; PAULINO, G.M.; FRANCO, A.A. Atributos químicos e microbianos de solos sob diferentes coberturas vegetais no norte do Estado do Rio de Janeiro. Revista Brasileira de Ciência do Solo, v.32, p.I52 I-I530, 2008.

GUIMARÃES, D.V.; GONZAGA, M.I.S.; SILVA, T.O.; SILVA, T.L.; DIAS, N.S.; MATIAS, M.I.S. Soil organic matter pools na carbono fractions in soil under different land uses. Soil and Tillage Research, v.126, p.I77-I82, 2013.

KARLEN, D.L.M.J.; MAUSBACH, J.W.; DORAN, R.G.; CLINE, R.F; HARRIS, AND G.E. SCHUMAN. Soil quality: A concept, definition, and framework for evaluation. Soil Science Society of America Journal, v.6I, p.4-10, 1997. Verificar referencia

KARLEN, D.L.; STOTT, D.E.; CAMBARDELLA, C.A.; KREMER, R.J.; KING, K.W.; MCCARTY, G.W. Surface soil quality in five midwestern cropland Conservation Effects Assessment Project watersheds. Journal of Soil and Water Conservation, v.69, p.393-40I, 2014.

KEMPER, W.D.; ROSENAU, R.C. Aggregate stability na size distribuition. Soil Science Society of America, v.677, p.425-442, 1986. 
KIEHL, E.J. Manual de edafologia - Relações solo-planta São Paulo, Agronômica Ceres, 1979. 262p

LOSS, A., PEREIRA, M.G.; SCHULTZ, N.; ANJOS, L.H.C.; SILVA, E.M.R. Carbono e frações granulométricas da matéria orgânica do solo sob sistemas de produção orgânica. Ciência Rural, v.39, n.4, p.78-83, 2009.

LOSS, A.; PEREIRA, M.G.; BERNINI, T.A.; ZATORRE, N.P.; WADT, P.G.S. Fertilidade do solo e matéria orgânica em Vertissolo e Argissolo sob cobertura florestal e pastagem. Comunicata Scientiae, v.5, n. I, p. 0I-I0, 2014.

MARCHINI, D.C.; LINF, T.C.; ALVES, M.C.; CRESTANA, S.; SOUTO FILHO, S.N.; ARRUDA, O.G. Matéria orgânica, infiltração e imagens tomográficas de Latossolo em recuperação sob diferentes tipos de manejo. Revista Brasileira de Engenharia Agrícola e Ambiental, v. 19 , n.6, p. 574-580, 2015.

MAZURANA, M.; LEVIEN, R.; INDA JUNIOR, A.V.; CONTE, O.; BRESSANI, L.A.; MÜLLER, J. Soil susceptibility to compaction under use conditions in southern Brazil. Ciência e Agrotecnologia, v. 4I, n. I, p. 60-7I, 2017.

MOLINE, E.F.V.; COUTINHO, E.L.M. Atributos químicos de solos da Amazônia Ocidental após sucessão da mata nativa em áreas de cultivo. Revista de Ciências Agrárias, v.58, n. I, p. I4-20, 2015.

MUELLER, B.C.; PAULA, F.S.; MIRZA, B.S.; RODRIGUES, J. L.M.; NUSSLEIN, K.; BOHANNAN, B.J.M. Links between plan and fungal communities across a deforestation chronosequence in the Amazon rainforest. The International Society for Microbial Ecology (ISME jornal), v.8, p.I548-I550, 2014.

NARESH, R.K.; VIVEK; KUMAR, S.; PURUSHATTOM.; SACHAN, D.K.; JAT, L.; MAHAJAN, N.C.; TIWARI, R.; TOMAR, S.S. Minimal soil disturbance and increased residue retention on aggregates carbono storage potencial and energy relations in Typic Ustochrept soil of Uttar Pradesh: A review. Jounal of Pharmacognosy and Phytichemistry, v.7, n.5, p.|429-1447, 2018.

NASCIMENTO, P. C.; BISSANI, C.A.; LEVIEN, R.; LOSEKANN, M. E.; FINATO, T. Uso da terra e atributos de solos do estado do Rio Grande do Sul. Revista Brasileira de Engenharia Agrícola e Ambiental, v. I8, n.9, p.920-926, 2014.

NIEWCZAS, J.; WITKOWSKA-WALCZAK, B. The soil aggregates stability index (ASI) and its extreme values. Soil and Tillage Research, v.80, p.69-78, 2005.

PORTUGAL, A.F.; JUNCKSH, I.; SCHAEFERE, C.E.R.G.; NEVES, J.C.L. Estabilidade de agregados em Argissolo sob diferentes usos, comparado com mata. Revista Ceres, v.57, n.4, p.545-553, 2010.

R DEVELOPMENT CORE TEAM. R: a language and environment for statistical computing. Vienna: $R$ Foundation for Statistical Computing, 2015. 409p.
REICHERT, J.M.; SUZUKI, L.E.A.S.; REINERT, D.J.; HORN, R. and HÄKANSSON, I. Reference bulk density and critical degree compactness for no-till crop production in subtropical highly weathered soils. Soil and Tillage Research., v. 102, p.242-254, 2009.

SALTON, J.C.; MERCANTE, F.M.; TOMAZI, M.; ZANATTA, J.A.; CONCENÇO, G.; SILVA, W.M.; RETORE, M. Integrated crop-livestock system in tropical Brazil: Toward a sustainable production system. Agriculture, Ecosystems and Environment, v.190, p.70-79, 2014.

SALTON, J.C.; SILVA, W.M.; TOMAZI, M.; HERNANI, L.C. Determinação da agregação do solo- Metodologia em uso na Embrapa Agropecuária Oeste. Comunicado técnico 184. Embrapa, 2012. 8 p.

SILVA, A.S.; SILVA, I.F.; FERREIRA, L.E.; BORCHARTT, L.; SOUZA, M.A.; PEREIRA, W.E. Propriedades físicas e químicas em diferentes usos do solo no brejo paraibano. Revista Brasileira de Ciência do Solo, v.37, p.10641072, 2013

SPACCINI, R.; PICCOLO, A. Effects of field managements for soil organic matter stabilization on water-stable aggregate distribuition and aggregate stability in three agricultural soils. Journal of Geochemical Exploration, v. 129, p.45-5I, 2013

STOTT, D.E., KARLEN D.L.; CAMBARDELLA, C.A.; HARMEL, R.D. A soil quality and metabolic activity assessment after fifty-seven years of agricultural management. Soil Science Society of America Journal, v.77, p.903-913, 2013.

TALEMA, A.; POESEN, J.; MUYS, B.; PADRO, R.; DIBABA, H.; DIELS,J. Survival and growth analysis of multipurpose trees, shrubs, and grasses used to rehabilitate badlands in the suhumid tropics. Land Degradation and Development, v.30, p.470-480, 2019.

TAYLOR, S.A.; ASHCROFT, G.L. Physical edaphology - The physics of irrigated and no irrigated soil. San Francisco, W.H. Freeman, 1972, 533 p.

TORMENA, C.A.; SILVA, A.P.; IMHOFF, S. DC.; DEXTER, A.R. Quantification of the soil physical quality of a tropical Oxisol using the index. Scientia Agricola, v.65, p.56-60, 2008.

TORRES, J.L.R.; PEREIRA, M.G.; MORAES, A.G.L.; BEUTLER, S.J. Frações granulométricas e oxidáveis da matéria orgânica em sistemas de colheita de cana-de-açúcar. Revista Caatinga, v.27, n.4, p.16-23, 2014.

TRIVEDI, P.; ROCHESTER, I.J.; TRIVEDI, C.; VAN NOSTRAND, J.D.; JHOU, J.; KARUNARATNE, S.; ANDERSON, I.C.; SINGH, B.K. Soil aggregate size mediates the impacts of cropping regimes on soil carbon and microbial communities. Soil Biology and Biochemistry, v.91, p.169-181, 2015.

VEIGA, M.; BALBINOT JUNIOR, A.A.; OLIVEIRA, D.A. Soil physical atributes in forms of sowing the anual winter pasture and intervals between grazing. Revista ciência Agronômica, v.45, n.5, p. 896-905, 2014. 
VEZZANI, F. M.; MIELNICZUK, J. Agregação e estoque de carbono em Argissolo submetido a diferentes práticas de manejo agrícola. Revista Brasileira de Ciência do Solo, v.35, p.213-223, 201 I.
ZORNOZA, R.; ACOSTA, J.A.; BASTIDA, F.; DOMINGUEZ, S.G.; TOLEDO, D.M.; FAZ, A. Identification of sensitive indicators to assess the interrelationship between soil quality, management practices and human health. Soil, v. I, p. $173-185,2015$. 